Portland State University

PDXScholar

Community Health Faculty Publications and

Presentations

School of Community Health

$1-1-2007$

\title{
Beyond Education: Improving the Prospects for Good Health
}

Stephanie Farquhar

Portland State University

Follow this and additional works at: https://pdxscholar.library.pdx.edu/commhealth_fac

Part of the Community Health and Preventive Medicine Commons

Let us know how access to this document benefits you.

\section{Citation Details}

Farquhar, S. (2007). Beyond education: improving the prospects for good health. Progress In Community Health Partnerships: Research, Education, and Action, 1(4), 295-296.

This Article is brought to you for free and open access. It has been accepted for inclusion in Community Health Faculty Publications and Presentations by an authorized administrator of PDXScholar. Please contact us if we can make this document more accessible: pdxscholar@pdx.edu. 


\section{Beyond Education: Improving the Prospects for Good Health}

Stephanie Farquhar

Portland State University, School of Community Health

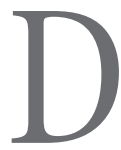
isparities in disease between different socioeconomic and racial/ethnic communities mean that certain communities in the United States, including African American, Latino, American Indian, and immigrant/refugee communities, face shorter life expectancies. These same communities also experience higher rates of cancer, asthma, infant mortality, diabetes, cardiovascular disease, HIV/AIDS, and violence. ${ }^{1-4}$ The National Institutes of Health and the Centers for Disease Control and Prevention have identified as primary to their missions the reduction or elimination of health disparities. As an example, the National Cancer Institute aims to "monitor the differential burden of cancer among Americans and ... [address] the economic, social, cultural, psychological, behavioral, and biological mechanisms contributing to these disparities.”

Yet, if we create programs and interventions that ignore the social, political, and economic factors that harm health, public health researchers and practitioners may place those populations we seek to help at greater risk. By only providing diseasespecific information and education, we inadvertently place the burden of sickness and healing on those who may be least able to "consume" the information. Research on social determinants has greatly expanded in recent years, such as the work by Wilkinson and Marmot. ${ }^{5}$ We know that social inequality contributes to health inequality. But the complexity of and political sensitivity about social determinants means these important variables are frequently overlooked in our work. We need to better translate systemic defects into contained and fundable interventions.

In this issue of Progress in Community Health Partnerships: Research, Education, and Action, Luque and his colleagues begin to address some of the problems that plague public health interventions. In their article, they describe the evaluation of an eye safety program with migrant citrus workers in Florida. Camp health aides, or promotores de salud, were trained using a set curriculum to guide and evaluate the program. The intervention is based on the supposition that peers are the most appropriate deliverers of information. Woven throughout the article is the acknowledgment that the delivery of health education information alone - without thinking about other barriers to good health — is inadequate. For example, Luque and colleagues discuss the devastating financial impact of being unable to work because of disability. For this population, good health is not optional; it is essential. The authors describe barriers to wearing protective glasses, including their potential for slowing down efficiency of harvesting and adversely affecting earning potential.

As practitioners, community members, and researchers interested in reducing health disparities, we can take this further. When evaluating threats to health and designing interventions to improve health, we must explicitly include racism, discrimination, lack of political power, and poverty. Farm workers in Oregon, surveyed as part of a community-based research project funded by the National Institutes of Health, not only report poor health and certain skin or breathing conditions associated with pesticide exposure; they also report that they feel trapped in their jobs as farm workers, their pay is inadequate, they have no voice or influence in the workplace, and they feel discriminated against for using their indigenous languages. We must tackle these issues in our programs and interventions if we truly hope to decrease health disparities.

There is an historical tension between individual responsibility and social accountability in public health programs. As Minkler ${ }^{6}$ reminded us almost a decade ago, and Wallack and Lawrence ${ }^{7}$ more recently, it is reasonable to assign some responsibility for making healthy choices to the individual. Yet we must understand that such choices are often limited by broader social, political, 
and economic constraints. What does this mean for public health programs? It means that we can supply information, education, and incentives for behavior change, but we must simultaneously advocate for public health policies that, as Nancy Milio ${ }^{8}$ has noted, make health-promoting choices more likely and health-damaging choices less likely. This means focusing on social and economic policies that can increase the level of fairness and justice in the society. And this means cleaning up polluted streams, changing discriminatory policies, advocating for universal health care, and empowering burdened communities.

More needs to be done. There are several recently issued funding mechanisms-including those released by the National Center on Minority Health and Health Disparities and the Robert Wood Johnson Foundation-that unambiguously require shared decision making with communities. By involving community members, agencies, labor organizations, and others in our research and practice, we jointly seek solutions to reduce health disparities. Ideally, community involvement begins before the team selects the priority health issues. It would be interesting to learn more about the specific process Luque and his colleagues used to identify eye injuries as the target problem, and whether there were other priorities that surfaced during the interviews and focus groups. Luque and colleagues discuss one way to involve and empower the citrus workers-the use of popular education techniques that recognize all participants as both teachers and learners. Popular education is intended as a means to repoliticize our work and address the power gap that is created when we deliver information void of political and cultural context. By funding programs that share power with those most affected, we have a realistic chance at a more equal distribution of good health.

In the end, we must remember that public health is ultimately about fairly distributing the burdens for prevention and the opportunities for good health. There is much of value in the approach of Luque and his colleagues. It also serves a reminder that we must take seriously the social, political, and economic dimensions of health.

\section{ACKNOWLEDGMENTS}

The author thanks Larry Wallack, Noelle Wiggins, Nancy Cuilwik, and Julie Samples for their insight and feedback on earlier drafts of this editorial.

\section{REFERENCES}

1. Williams DR. Race, SES and health: The added effects of racism and discrimination. In: Brown P, editor. Perspectives in medical sociology. 3rd ed. Prospect Heights (IL): Waveland Press; 2000. p. 21-39.

2. Raphael D, editor. The social determinants of health. Toronto: Canadian Scholars Press; 2004.

3. Krieger N. Embodying inequality: Epidemiologic perspectives. Amityville: Baywood; 2005.

4. Cwikel J. Social epidemiology. New York: Columbia University Press; 2007.

5. Wilkinson R, Marmot M, editors. Social determinants of health: The solid facts. 2nd ed. Geneva: World Health Organization; 2003.

6. Minkler M. Personal responsibility for health? A review of the arguments and the evidence at century's end. Health Educ Behav. 1999;26:121-41.

7. Wallack L, Lawrence R. Talking about public health: Developing America’s “second language.” Am J Public Health. 2005;95:567-70.

8. Milio N. Promoting health through public policy. Philadelphia: FA Davis; 1981. 